\title{
Biochemical Basis of Low Fruit Quality of Prunus davidiana, a Pest and Disease Resistance Donor for Peach Breeding
}

\author{
Annick Moing ${ }^{1}$ \\ Unité de Recherches sur les Espèces Fruitières et la Vigne, Institut National de la Recherche Agronomique, \\ Centre de Bordeaux, BP 81, F-33883 Villenave d'Ornon, cedex, France \\ Jean-Luc Poëssel \\ Unité de Génétique et d'Amélioration des Fruits et Légumes, Institut National de la Recherche \\ Agronomique, Domaine St Paul, Site AgroParc, F-84914 Avignon, cedex 9, France
}

\section{Laurence Svanella-Dumas}

Unité de Recherches sur les Espèces Fruitières et la Vigne, Institut National de la Recherche Agronomique, Centre de Bordeaux, BP 81, F-33883 Villenave d'Ornon, cedex, France

\author{
Michèle Loonis and Jocelyne Kervella \\ Unité de Génétique et d'Amélioration des Fruits et Légumes, Institut National de la Recherche \\ Agronomique, Domaine St Paul, Site AgroParc, F-84914 Avignon, cedex 9, France
}

\begin{abstract}
AdDitional INDEX words. fruit quality, organic acids, phenolics, soluble sugars, amino acids, anthocyanins
Abstract. Prunus davidiana (Carr.), a wild species with poor fruit quality that is related to peach [Prunus persica (L.) Batsch], is used as a source of resistance to pests and diseases in peach breeding programs. Two genotypes of $P$. davidiana were studied for fruit biochemical composition and compared to three genotypes of $P$. persica ('Summergrand', 'Bailey' and 'Pamirskij'), and two $P$. persica $\times$ P. davidiana hybrids. Fruit of $P$. davidiana clones had higher malic acid, neochlorogenic and cryptochlorogenic acid and lower sucrose concentrations than fruit of all $P$. persica genotypes, even poor-quality Bailey. Differences in biochemical composition could be related to sensory evaluation. $P$. persica $x \boldsymbol{P}$. davidiana hybrids had intermediate values between their parents for neochlorogenic acid concentration. They were similar to the $\boldsymbol{P}$. persica parent for total soluble sugar, malic and citric acid, amino acid and catechin concentrations, indicating possible rapid progress for fruit quality in a breeding program.
\end{abstract}

New cultivar development in peach exceeds that of all temperate fruit crops (Fideghelli et al., 1998). However, due to the narrow germplasm of commercial cultivars (Scorza et al., 1985), genetic resources for resistance to pests and diseases have to be investigated in related undomesticated species. Prunus davidiana (Carr.), originating from northwest China (Li, 1984), has been identified as a source of resistance to green peach aphid (Massonié et al., 1982), plum pox virus, powdery mildew and peach leaf curl (Shoferistov, 1988). Interspecific crosses between P. persica and $P$. davidiana have been developed (Kervella et al., 1998; Scorza and Okie, 1990). Undomesticated species such as $P$. davidiana are also characterized by poor fruit size, color and flavor, requiring intensive selection efforts to recover commercial quality. Preliminary subjective evaluations in our laboratory indicated that $P$. davidiana fruit were of lower quality than those of the peach rootstock, 'Bailey', a low fruit quality genotype.

Biochemical characteristics responsible for poor fruit quality have been identified through the comparison of low and high quality peach genotypes (Robertson et al., 1988). Although knowledge of the biochemistry of fruit quality is limited, the main

Received for publication 1 Feb. 2002. Accepted for publication 9 Sept. 2002. We thank F. Pfeiffer for taking care of the trees, F. Laigret and M. Faurobert for critical reading of the manuscript, and the Translation and Terminology Division of INRA at Jouy-en-Josas for correcting the English.

${ }^{1}$ Corresponding author. Present address: UMR Physiologie et Biotechnologie Végétales, Institut National de la Recherche Agronomique, Centre de Bordeaux, BP 81, F-33883 Villenave d'Ornon, cedex, France. e-mail: moing@bordeaux.inra.fr. compounds of fruit flesh which affect fruit quality have been identified. Soluble sugars and organic acids are commonly studied in relation to sweetness and tartness (Bassi and Selli 1990; Brady, 1993). Phenolics, involved in flesh browning (Cheng and Crisosto, 1995; Radi et al., 1997), also influence fruit bitterness and astringency (Macheix et al., 1990), and have been reported to differ between high- and low-quality peach genotypes (Robertson et al., 1988).

Specific biochemical compounds associated with low fruit quality of $P$. davidiana, were determined by comparing the fruit biochemical composition of a commercial quality peach ('Summergrand'), two low-quality P. persica genotypes commonly used as rootstocks, two $P$. davidiana genotypes, and two P. persica $\times$ P. davidiana $\mathrm{F}_{1}$ hybrids. Knowledge of the biochemical basis of poor fruit quality in such wild species and interspecific hybrids will allow for the development of appropriate breeding strategies to develop pest and disease resistant commercial peach cultivars when using wild species as donors.

\section{Materials and Methods}

Plant material. Fruit were harvested at Avignon (France) during July and August 1997 from seven genotypes used in the French INRA peach breeding program. 'Bailey' is a whitefleshed cultivar of $P$. persica resistant to peach leaf curl. It was selected as a peach rootstock in the United States (Layne and Jui, 1994), but has poor fruit quality (Robertson et al., 1988; Scorza et al., 1991). 'Pamirskij' is a seedling of 'Pamirskij 5', a P. persica 
rootstock from Russia, resistant to powdery mildew (issued from seeds sent by Pr. Eremin, Vavilov Institute, Krymsk). 'Summergrand' is a commercial yellow-fleshed nectarine $[P$. persica (L.) Batsch var. nectarina) originating from a cross between 'Late Legrand' and 'Early Sungrand' made in California and released by Reedley Nursery (Okie, 1998). P. davidiana clone P 1908 was introduced into France from the Arnold Arboretum (United States). $P$. davidiana clone 2 was introduced into France from China. SxD 31 and SxD 17 are interspecific hybrids between 'Summergrand' and P. davidiana P 1908, developed at INRA Avignon (France) and selected for resistance to powdery mildew. All genotypes were grafted on GF 305 seedling rootstock ( $P$. persica) and grown outdoors in 30-L pots containing a 60 black peat : 40 white peat mixture (by volume) (BF1) substrate from De Baat, Coervorden, Netherlands). Each genotype was represented by two trees. Pest and disease control was as usual for peach. The trees were 2 or 3 years old at the time of the experiment.

Fifteen fruit were harvested at maturity for each cultivar from the two trees. Maturity criteria used to establish harvest date were based on texture for all genotypes and color characteristics for $P$. persica genotypes. Fresh weight of 10 individual fruit and their stones was determined. An overall notation of the dominant color and percentage of red color of the skin was carried out visually on this 10-fruit sample. A portion of each fruit was used for $\mathrm{pH}$ and titratable acidity measurements. The rest of the 10 fruit was cut into slices for evaluating juiciness with a four class scale (not juicy, a little juicy, juicy, very juicy), or frozen at $-20{ }^{\circ} \mathrm{C}$ until sensory evaluation. Five individual fruit were used for determining dry matter content and biochemical analyses. Dry matter content was determined after drying in an oven at $80{ }^{\circ} \mathrm{C}$ until constant weight. For chemical analyses, $5 \mathrm{~g}$ of flesh, i.e., mesocarp, or skin, i.e., epidermis plus $\approx 1 \mathrm{~mm}$ thick mesocarp, from each individual fruit were ground in liquid nitrogen, fractionated in $1 \mathrm{~g}$ samples and stored at $-20{ }^{\circ} \mathrm{C}$ until analyzed.

Sensory EVAluation. Sensory evaluation was conducted on frozen fruit because of the different dates of maturity. A preliminary study comparing fresh and frozen fruit slices of four genotypes, showed that freezing had little effect on the perception of sweetness, tartness, bitterness, and astringency (data not shown). Frozen slices of mesocarp were thawed at $4{ }^{\circ} \mathrm{C}$ and then equilibrated at room temperature. A panel of nine people rated each genotype for preference, sweetness, tartness, bitterness and astringency. For $P$. davidiana $\mathrm{P} 1908$, only two people could taste the fruit due to the small quantity of fruit samples. The simplified scale of Robertson et al. (1988) was used to evaluate fruit preferences: $1=$ unacceptable, $2=$ poor, $3=$ acceptable, $4=$ good, and $5=$ excellent. A similar scale was used for the other taste parameters: $1=$ not detected, $2=$ low, $3=$ medium, $4=$ high, and 5 = very high.

JUICE PH AND ACIDITY MEASUREMENTS. Mesocarp samples ( 2 to $3 \mathrm{~g}$ fresh weight) were immediately frozen in liquid nitrogen in a $5 \mathrm{~mL}$ syringe containing a small paper filter at the needle. After thawing at $4{ }^{\circ} \mathrm{C}$, the juice was extracted by hand pressing. The acidity of the juice was determined by measuring the $\mathrm{pH}$ of a $1 \mathrm{~mL}$ sample using a pH meter (Schott Geräte, Germany). Titratable acidity was determined by titration of a 1-mL sample of juice diluted $\left(1: 5\right.$, by volume) with distilled water with $0.1 \mathrm{~mol} \cdot \mathrm{L}^{-1}$ $\mathrm{NaOH}$ to a $\mathrm{pH}$ of 8.3 .

DETERMINATION OF SUGARS, ORGANIC ACIDS AND AMINO ACIDS. One gram of fruit flesh ground in liquid nitrogen was extracted twice with ethanol at $80^{\circ} \mathrm{C}$ as described previously (Moing et al.,
1998). Extracts were dried under vacuum, dissolved in pure water, and used for analysis of soluble sugars, organic acids and amino acids. Starch content was determined on the pellet, after hydrolysis with amyloglucosidase (Moing et al., 1992).

Soluble sugars were analyzed by anion-exchange high performance liquid chromatography (HPLC) with amperometry detection (CarboPac PA1 column from Dionex Corp. Sunnyvale, Calif.), as described by Moing et al. (1997) but without previous purification on ion-exchange resins. The total soluble carbohydrates is the sum of sucrose, glucose, fructose, sorbitol, xylose and inositol.

Organic acids were analyzed without sample purification, using anion-exchange HPLC (IonPac AS-11 4 mm column and ATC pre-column from Dionex Corp., Sunnyvale, Calif.) as described by Moing et al. (1998). Besides malic, citric, quinic, isocitric and oxalic acids which could be quantified in all samples, succinic and fumaric acids were present as traces in most samples, but could not be quantified. The total organic acids is the sum of malic, citric, quinic, isocitric and soluble oxalic acids.

Amino acids were analyzed by HPLC, without sample purification, using the AccQ.Tag method from Waters (Milford, Mass.). Amino acids derivatized with 6-aminoquinolyl-N-hydroxysuccinimidyl carbamate (Cohen and Michaud, 1993) were detected by fluorescence (excitation at $250 \mathrm{~nm}$ and emission at 394 $\mathrm{nm}$ ) with a FL 2000 dual monochromator fluorescence detector from Thermo Separation Products (San Jose, Calif.). The total amino acids is the sum of all amino acids except tryptophan.

Sugar, organic acids and amino acids were quantified with Millenium software from Waters (Milford, Mass.). HPLC peaks were identified by co-chromatography with commercial standards, their area were calculated, and calibration was carried out with known quantities of sugar, organic acid, or amino acid from Sigma (St. Quentin Fallavier, France).

Determination of Phenolics and anthocyanins. Caffeoylquinic acids (CQ), the predominant phenolic acids, and catechin, a predominant flavonoid of stone fruit, were determined in flesh, and anthocyanins were determined in both flesh and skin. One gram of fruit flesh or skin ground in liquid nitrogen with a mortar and pestle was extracted three times with cold 80 ethanol : 20 water (by volume) for $15 \mathrm{~min}$ at $4{ }^{\circ} \mathrm{C}$. 6-methoxyflavone was added in the ethanol:water extraction solvent and used as internal standard. After centrifugation at $2600 \mathrm{~g}_{\mathrm{n}}$ for $10 \mathrm{~min}$, the supernatants were combined and dried under vacuum. Dried extract was dissolved in $1 \mathrm{~mL}$ of HPLC-grade methanol. A $0.5 \mathrm{~mL}$ volume of the extract was diluted with $0.5 \mathrm{~mL}$ methanol and used for phenolic determination. The rest of the extract was diluted with $0.5 \mathrm{~mL}$ of methanol containing $0.1 \%$ concentrated $\mathrm{HCl}$ and used for anthocyanin determination. Both diluted methanolic extracts were filtered through a $0.45 \mu \mathrm{m}$ PTFE filter unit before HPLC separation. Phenolics and anthocyanins were analyzed, using reverse phase HPLC, with a Lichrocart column $(250 \times 4 \mathrm{~mm})$ from Merck (Darmstadt, Germany) filled with a $4 \mu \mathrm{m}$ Superspher 100 RP18 endcapped solid phase. Elution solvents were: A, pure water acidified to $\mathrm{pH} 2.6$ with orthophosphoric acid; B, HPLCgrade methanol. The column was maintained at $30^{\circ} \mathrm{C}$ in an oven. For phenolics, a flow rate of $0.5 \mathrm{~mL} \cdot \mathrm{min}^{-1}$ was used with the following gradient: 0 to $5 \mathrm{~min}, 3 \% \mathrm{~B} ; 10 \mathrm{~min}, 12 \% \mathrm{~B} ; 13$ to $18 \mathrm{~min}$, $13 \% \mathrm{~B} ; 20$ to $26 \mathrm{~min}, 14 \% \mathrm{~B} ; 30$ to $35 \mathrm{~min}, 16 \% \mathrm{~B} ; 37$ to $47 \mathrm{~min}$, $17 \% \mathrm{~B} ; 60 \mathrm{~min}, 19 \% \mathrm{~B} ; 65$ to $70 \mathrm{~min}, 23 \% \mathrm{~B}$. At $65 \mathrm{~min}$ the flow was changed in $2 \mathrm{~min}$ to $0.7 \mathrm{~mL} \cdot \mathrm{min}^{-1}$ with the following gradient : 90 min, 60\% B; 95 min, 100\% B. Eluted components were monitored with a dual wavelength detector at 280 or $330 \mathrm{~nm}$ 
during the first $95 \mathrm{~min}$ and then at $315 \mathrm{~nm}$ and $330 \mathrm{~nm}$ during 5 min for detecting the internal standard (Fig. 1). For anthocyanins, a flow rate of $0.7 \mathrm{~mL} \cdot \mathrm{min}^{-1}$ was used with the following gradient: 0 to $2 \mathrm{~min}, 10 \% \mathrm{~B} ; 22 \mathrm{~min}, 65 \% \mathrm{~B} ; 27$ to $32 \mathrm{~min}, 100 \% \mathrm{~B}$. The eluted components were monitored at 530 and $550 \mathrm{~nm}$ during the first $22 \mathrm{~min}$ and then at $315 \mathrm{~nm}$ and $330 \mathrm{~nm}$ for detecting the internal standard. The components were identified by co-chromatography with known standards when available (chlorogenic acid, catechin and cyanidin-3-glucoside from Extrasynthèse, Genay, France). Neochlorogenic (3'-caffeoylquinic acid, 3'CQ) and cryptochlorogenic (4'-caffeoylquinic acid, 4'CQ) acids were obtained by isomerization of chlorogenic acid according to Möller and Herrmann (1982). Components were quantified using commercial standards for chlorogenic acid, catechin and cyanidin-3glucoside, or expressed in chlorogenic acid equivalents for $3{ }^{\prime} \mathrm{CQ}$ and 4'CQ. The total caffeoylquinic acids (sum CQ) is the sum of chlorogenic, neochlorogenic and cryptochlorogenic acids. Only trans isomers of caffeoylquinic acids were considered.

Determination of Proanthocyanidins. Proanthocyanidins (condensed tannins) were estimated based on their conversion to anthocyanidins upon acid hydrolysis with butanol: $\mathrm{HCl}$ (Porter et al., 1986). They were determined at $550 \mathrm{~nm}$ on the extract used for phenolic determination. Resulting value was used to calculate the proanthocyanidin concentration of the sample using the absorbance coefficient at $550 \mathrm{~nm}$ determined by Porter et al. (1986) on procyanidin polymer from Chaenomeles sinensis (Koehne) fruit:
490 for a solution containing $1 \mathrm{~g} / 100 \mathrm{~mL}$ and an absorption path of $1 \mathrm{~cm}$.

STATISTICAL ANALYSIS. For biochemical variables, genotypes were compared using Tukey's test $(P<0.05)$ after variance analysis, with SAS software version 6.11 (SAS Institute, Cary, N.C.). For sensory evaluations, multiple comparisons between genotypes were performed according to the distribution-free procedure based on Kruskal-Wallis rank means (Hollander and Wolfe, 1973) after Kruskal-Wallis test for genotype effect. Thresholds for rank means were computed by simulation. Five thousand runs were performed to determine thresholds of rank means corresponding to experiment wise error rates of $5 \%$. Biochemical variables and sensory evaluations were compared using Spearman rank correlation coefficients.

\section{Results}

FrUIT WEIGHT, SENSORY EVALUATION AND JUICE CHARACTERISTICS. Maturity date ranged from 3 July, for $P$. davidiana P 1908, to 15 August for 'Bailey' (Table 1). In our growth conditions, all genotypes except 'Summergrand' yielded small fruit with a fresh weight lower than $80 \mathrm{~g}$ (Table 1). Prunus davidiana genotypes had a mean fruit fresh weight $<20 \mathrm{~g}$ with a very low flesh to kernel ratio. Dry matter content of the flesh at maturity ranged from $12.5 \%$ to $17.4 \%$ fresh matter according to the genotype (Table 1 ). $P$. davidiana genotypes, and 'Pamirskij' had mature fruit with a

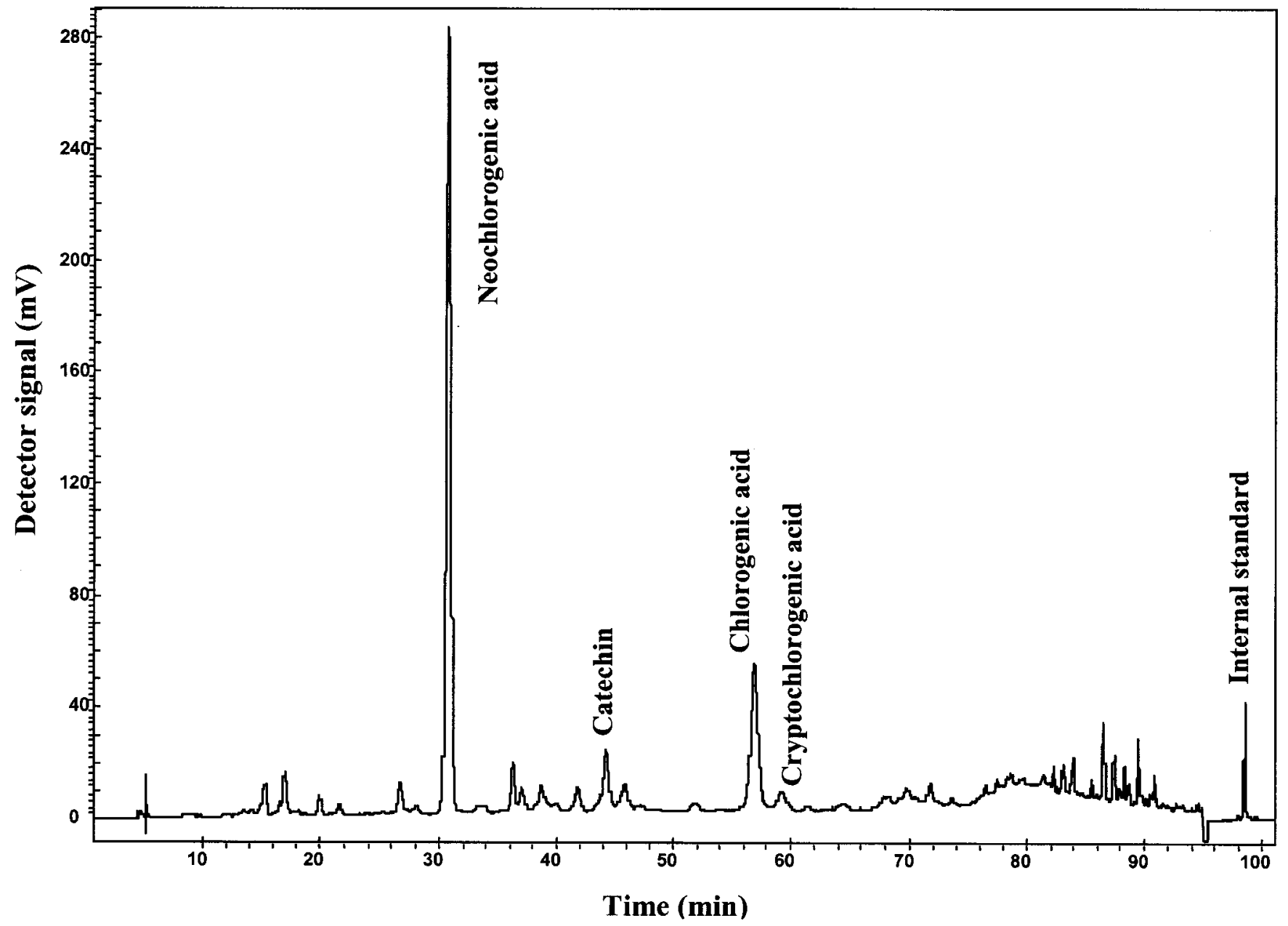

Fig. 1. Reverse phase HPLC separation of phenolic compounds from ripe fruit mesocarp of SxD 17 Prunus persica $x$ P. davidiana hybrid. The detection wavelength shown is $280 \mathrm{~nm}$ for the first $95 \mathrm{~min}$, and $315 \mathrm{~nm}$ for the following $5 \mathrm{~min}$ for internal standard detection. 
greenish epidermis, without any red portion. Only 'Summergrand' showed a nearly entirely red epidermis (Table 2). The flesh was scored not juicy for $P$. davidiana, very juicy for 'Summergrand' and 'Pamirskij' and juicy for the other genotypes.

According to sensory evaluation of frozen fruit flesh (Table 3), 'Summergrand' and 'Pamirskij' were the preferred genotypes and were rated the least bitter and astringent. 'Pamirskij' was rated the sweetest and least tart genotype. $P$. davidiana genotypes were rated the most bitter. However, the two $P$. davidiana genotypes differed significantly for astringency; $P$. davidiana 2 was the most astringent, and $P$. davidiana $\mathrm{P} 1908$ was rated as nonastringent like 'Summergrand'. SxD hybrids were rated similar to their parents for tartness, similar to their $P$. davidiana parent for bitterness, and similar to their $P$. persica parent for sweetness.

The juice SSC (Table 4) was significantly lower in P. davidiana genotypes than in all the other studied genotypes. It was significantly higher in 'Pamirskij' and $\mathrm{SxD} 31$, reaching $\approx 15 \%$. The juice titratable acidity (Table 4) was not significantly different between 'Summergrand', SxD hybrids and $P$. davidiana genotypes. The titratable acidity of 'Pamirskij' and 'Bailey' was significantly lower than that of the other genotypes. No clear separation between species could be obtained for juice $\mathrm{pH}$, with the lowest $\mathrm{pH}$ value being observed for 'Summergrand' and the highest values for $P$. davidiana and 'Pamirskij'. Intermediate $\mathrm{pH}$ values were obtained for the SxD hybrids.

Carbohydrates. For all genotypes, the major soluble sugar in flesh at maturity was sucrose, and starch concentration was $<2$ $\mathrm{mg} \cdot \mathrm{g}^{-1}$ dry weight (Table 5). The total soluble carbohydrate concentration for 'Summergrand', 'Pamirskij' and SxD hybrids ranged from 700 to $900 \mathrm{mg} \cdot \mathrm{g}^{-1}$ dry weight. 'Bailey' had a total soluble carbohydrate concentration of $\approx 500 \mathrm{mg} \cdot \mathrm{g}^{-1}$ dry weight and a very low fructose concentration. The $P$. davidiana genotypes had a total soluble carbohydrate concentration $<80 \mathrm{mg} \cdot \mathrm{g}^{-1}$ dry weight and they were also characterized by a very low sorbitol concentration compared to other genotypes.

OrganIC ACIDS. The three major organic acids in flesh at maturity were malic acid, citric acid and free quinic acid in all genotypes (Table 6). The sum of organic acids was the highest in $P$. davidiana genotypes, $\approx 130 \mathrm{mg} \cdot \mathrm{g}^{-1}$ dry weight, due to a high malic acid concentration. Since $P$. davidiana genotypes also had a very low citric acid concentration, they were characterized by a high malic/citric acid concentration ratio (up to 50 in $P$. davidiana $\mathrm{P} 1908$ ). For $P$. persica genotypes or $\mathrm{SxD}$ hybrids, malic acid concentration ranged from 20 to $50 \mathrm{mg} \cdot \mathrm{g}^{-1}$ dry weight and the malic to citric acid ratio was 1 to $2.5 \mathrm{mg} \cdot \mathrm{g}^{-1}$ dry weight. $P$. davidiana genotypes tended to have less free quinic acid than the other genotypes.

Amino ACIDS. For all genotypes, the major amino acid in flesh at maturity was asparagine (Table 7), representing $>80 \%$ of the total amino acids. The concentration of asparagine in $P$. davidiana genotypes ( $\approx 70 \mathrm{mg} \cdot \mathrm{g}^{-1}$ dry weight) was significantly higher than in the other genotypes. Aspartate concentration reached $1.8 \mathrm{mg} \cdot \mathrm{g}^{-1}$ dry weight in $P$. davidiana $\mathrm{P} 1908$ and was significantly lower in other genotypes. Serine concentration was $<1.3 \mathrm{mg} \cdot \mathrm{g}^{-1} \mathrm{dry}$ weight in all genotypes.

Phenolics. Caffeoylquinic acids were the major phenolics in the fruit flesh in all genotypes. However, the concentration of the different isomers differed greatly according to the genotype: the major caffeoylquinic acid was 3'CQ for all genotypes, except 'Bailey' and 'Pamirskij' where it was 5'CQ (Table 8). 3'CQ and 4'CQ concentrations were significantly higher in $P$. davidiana genotypes than in the other genotypes. Therefore, the highest concentration in the sum of caffeoylquinic acids was observed in the fruit flesh of $P$. davidiana genotypes where it reached $\approx 9$

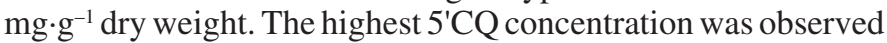
in 'Bailey' (3.1 $\mathrm{mg} \cdot \mathrm{g}^{-1}$ dry weight) and the lowest in $P$. davidiana genotypes.

Catechin was the main flavan-3-ol compound identified in the flesh of all genotypes. Epicatechin, detected in very low concentration in all genotypes, was not considered in this study. Other compounds, probably proanthocyanidin oligomers, were observed on chromatograms but were not analyzed. Catechin concentration varied greatly among genotypes. The highest catechin concentration was observed in $P$. davidiana $2\left(5.1 \mathrm{mg} \cdot \mathrm{g}^{-1}\right.$ dry weight). However, the fruit flesh of $P$. davidiana $\mathrm{P} 1908$ had a catechin concentration $\approx 3$ times lower than $P$. davidiana 2 . The lowest catechin concentration was observed in 'Summergrand' $\left(0.2 \mathrm{mg} \cdot \mathrm{g}^{-1} \mathrm{dry}\right.$ weight $)$. 'Bailey' had the highest catechin concentration of the $P$. persica genotypes.

Proanthocyanidins. The proanthocyanidin concentration in the fruit flesh was significantly higher in $P$. davidiana 2 (6.51 $\mathrm{mg} \cdot \mathrm{g}^{-1}$ dry weight) than in the other genotypes where it ranged from 0.37 to $1.78 \mathrm{mg} \cdot \mathrm{g}^{-1}$ dry weight, the lowest concentration being observed in 'Summergrand' and 'Pamirskij' (Table 8). 'Bailey' had the highest concentration among $P$. persica genotypes. Surprisingly, the fruit flesh of $P$. davidiana $\mathrm{P} 1908$ had a proanthocyanidin concentration $\approx 8$ times lower than $P$. davidiana 2 .

Anthocyanins. Cyanidin-3-glucoside was the only anthocyanin detected in fruit samples. The highest cyanidin-3-glucoside concentrations were observed in the fruit flesh and skin of 'Summergrand' (Table 9). In the skin of 'Summergrand' fruit, cyanidin-3-glucoside reached a concentration of $\approx 6.5 \mathrm{mg} \cdot \mathrm{g}^{-1} \mathrm{dry}$

Table 1. Maturity date, fruit weight and flesh percent dry weight in Prunus persica, $P$. davidiana, and hybrid genotypes.

\begin{tabular}{lcccc}
\hline \hline & $\begin{array}{c}\text { Maturity } \\
\text { date }\end{array}$ & $\begin{array}{c}\text { Fruit } \\
\mathrm{wt} \\
(\mathrm{g})\end{array}$ & $\begin{array}{c}\text { Flesh to } \\
\text { kernel } \\
\text { ratio }\end{array}$ & $\begin{array}{c}\text { Flesh } \\
\text { dry } \\
\text { wt }(\%)\end{array}$ \\
\hline Summergrand & 17 July 17 & $174.0 \mathrm{a}^{\mathrm{z}}$ & $15.8 \mathrm{a}$ & $13.0 \mathrm{~cd}$ \\
Bailey & 15 Aug. & $75.5 \mathrm{~b}$ & $14.0 \mathrm{ab}$ & $12.5 \mathrm{~d}$ \\
Pamirskij & 21 July & $37.2 \mathrm{bc}$ & $11.4 \mathrm{~b}$ & $15.4 \mathrm{~b}$ \\
SxD 31 & 17 July & $46.8 \mathrm{bc}$ & $5.9 \mathrm{c}$ & $14.4 \mathrm{~b}$ \\
SxD 17 & 17 July & $32.5 \mathrm{c}$ & $6.0 \mathrm{c}$ & $17.4 \mathrm{a}$ \\
$P$. davidiana 2 & 3 July & $18.2 \mathrm{c}$ & $2.4 \mathrm{~d}$ & $14.0 \mathrm{bcd}$ \\
$P$. davidiana P 1908 & 3 July & $15.2 \mathrm{c}$ & $2.1 \mathrm{~d}$ & $12.5 \mathrm{~d}$
\end{tabular}

${ }_{\mathrm{z}}$ Mean of 10 fruit for fruit fresh weight and the ratio between flesh and kernel fresh weight, and 5 fruit for flesh dry weight, expressed as percentage of fresh weight. Mean separation within columns according to Tukey's test, $P<0.05$.

Table 2. Fruit epidermis color of Prunus persica, P. davidiana, and hybrid genotypes.

\begin{tabular}{lcc}
\hline \hline & \multicolumn{2}{c}{ Epidermis color } \\
\cline { 2 - 3 } Genotype & Dominant color & \% Red \\
\hline Summergrand & bright red & 90 \\
Bailey & pink violet & 60 \\
Pamirskij & light green & 0 \\
SxD 31 & light green & $10-30$ \\
SxD 17 & light green & $10-30$ \\
P. davidiana 2 & light green & 0 \\
P. davidiana P 1908 & light green & 0
\end{tabular}

${ }^{\mathrm{z}}$ Overall visual notation of 10 fruit. 
Table 3. Sensory evaluation of fruit of Prunus persica, P. davidiana, and hybrid genotypes.

\begin{tabular}{|c|c|c|c|c|c|}
\hline Genotype & Preference & Sweetness & Tartness & Bitterness & Astringency \\
\hline Summergrand & $3.1 \mathrm{bc}^{\mathrm{z}}$ & $3.0 \mathrm{~b}$ & $3.1 \mathrm{abc}$ & $1.1 \mathrm{a}$ & $1.2 \mathrm{ab}$ \\
\hline Bailey & $1.9 \mathrm{ab}$ & $2.3 \mathrm{~b}$ & $2.3 \mathrm{ab}$ & $2.7 \mathrm{~b}$ & $2.0 \mathrm{ab}$ \\
\hline Pamirskij & $3.3 \mathrm{c}$ & $3.6 \mathrm{~b}$ & $1.9 \mathrm{a}$ & $1.1 \mathrm{a}$ & $1.2 \mathrm{ab}$ \\
\hline SxD 31 & $2.1 \mathrm{abc}$ & $2.1 \mathrm{ab}$ & $3.3 \mathrm{bc}$ & $2.4 \mathrm{~b}$ & $2.0 \mathrm{ab}$ \\
\hline SxD 17 & $1.4 \mathrm{a}$ & $2.3 \mathrm{~b}$ & $2.9 \mathrm{abc}$ & $2.9 \mathrm{~b}$ & $2.4 \mathrm{bc}$ \\
\hline P. davidiana 2 & $1.0 \mathrm{a}$ & $1.0 \mathrm{a}$ & $2.9 \mathrm{abc}$ & $3.8 \mathrm{~b}$ & $4.1 \mathrm{c}$ \\
\hline P. davidiana P 1908 & $1.0 \mathrm{a}$ & $1.0 \mathrm{a}$ & $4.0 \mathrm{c}$ & $3.0 \mathrm{~b}$ & $1.0 \mathrm{a}$ \\
\hline
\end{tabular}

${ }^{\mathrm{z}}$ Mean notation by nine untrained individuals $(\mathrm{n}=9)$ for all genotypes, except for $P$. davidiana $\mathrm{P} 1908$ where there were only two individuals $(\mathrm{n}=$ 2). For preference, a simplified scale was used: $1=$ unacceptable, $2=$ poor, $3=$ acceptable, $4=$ good, $5=$ excellent. The other taste parameters were rated according to the following scale: $1=$ not detected, $2=$ low, $3=$ medium, $4=$ high, $5=$ very high. Separation within columns according to the distribution-free procedure based on Kruskal-Wallis rank means, $P<0.05$.

weight, whereas it was not detected in the skin or flesh of $P$. davidiana genotypes and 'Pamirskij'. SxD hybrids and 'Bailey' had values similar to that of 'Summergrand' for flesh and values significantly lower than 'Summergrand' for skin.

CORRelation betWeen biochemical analyses AND taSTe PARAMETERS. Variations in sweetness perception were highly correlated to variations in total soluble sugar concentration and in sucrose concentration (Spearman rank correlation coefficient rho $=0.94, P=0.04)$. Tartness rates were roughly ordered as the sum of malic, citric and quinic acid concentrations (rho $=0.66, P$ $=0.15$ ). Malic acid concentration seemed to have a lesser impact on tartness than citric and quinic acids. Indeed, $P$. davidiana 2 , with a significantly higher total acid concentration but a lower citric + quinic to malic ratio than SxD 17 and SxD 31 was rated as sour as $\operatorname{SxD} 17$ and less sour than SxD 31. Astringency scores were ordered as mean proanthocyanidin concentration $($ rho $=$ $0.93, P=0.03)$. The most astringent genotype $(P$. davidiana 2$)$ had the highest proanthocyanidin concentration.

\section{Discussion}

CONSISTENCY WITH PREVIOUS STUDIES OF BIOCHEMICAL FRUIT COMPOSITION IN PEACH. The concentrations of soluble sugars and organic acids observed in $P$. persica genotypes were in general agreement with published data (Byrne et al., 1991). Amino acid concentrations observed for $P$. persica genotypes were slightly higher than those reported by Moing et al. (1998). Our data on phenolics in $P$. persica genotypes were in agreement with total phenolics reported by Bassi and Selli (1990). Caffeoylquinic acids were the predominant phenolic acids as found in other stone fruit, and their concentration was equivalent to that previously published for peach fruit (Herrmann, 1989). For 'Bailey' fruit, the relative importance of major sugars and the concentration of phenolics were quite similar to that observed by Robertson et al. (1988). Cyanidin-3-glucoside was the main anthocyanin in all genotypes as previously observed in peaches (Van Blaricom and Senn, 1967).

CORRELATION BETWEEN BIOCHEMICAL ANALYSES AND SENSORY EVALUATION. Although the sensory evaluation by untrained people only provided general results, correlations between sensory evaluation and biochemical composition in fruit mesocarp were high, probably a consequence of large differences between the genotypes evaluated. Variations in sweetness perception were highly correlated to variations in total soluble sugar and sucrose concentrations. Tartness ratings were generally ranked as the sum of malic, citric and quinic acid concentrations. Astringency scores were ranked as mean proanthocyanidin concentration, although differences in proanthocyanidin levels were not declared significant after Tukey's test. The most astringent genotype ( $P$. davidiana 2) had the highest tannin concentration (catechin and proanthocyanidins). The higher level of phenolics (Robertson et al., 1988) or condensed tannins (Senter and Callahan, 1990) in low-quality, astringent peaches was previously confirmed on different genotypes including 'Bailey'. In our study, 'Bailey' also showed the highest catechin and proanthocyanidin levels among P. persica genotypes. Anthocyanin concentrations in the skin were generally in agreement with percentage of red color in epidermis.

BIOCHEMICAL TRAITS RESPONSIBLE FOR LOW QUALITY OF $\boldsymbol{P}$. davidiana FRUIT. When compared to $P$. persica, $P$. davidiana genotypes differed strongly in quantitative and qualitative composition of three classes of nonvolatile compounds influencing fruit taste; they were characterized by lower concentration of total soluble sugars, especially lower sucrose concentration, lower concentration of citric acid, and higher concentration of malic acid, aspartate, neochlorogenic and cryptochlorogenic acids and catechin.

Low sugar concentration $(\approx 5$ to 10 times less than in P. persica fruit) was responsible for insufficient sweetness of $P$. davidiana flesh. This was a major difference between $P$. davidiana and lowquality peaches such as 'Bailey', since in the present study, total soluble sugar concentration in 'Bailey' reached half of that in high-quality 'Summergrand'. High malic acid concentration in $P$. davidiana fruit (four to six times higher than in P.persica fruit) seemed to be compensated for by low citric acid concentration (three to 10 times lower than in P.persica fruit), since these strong variations had little impact on fruit acidity and tartness.

The high phenolic concentration of the two $P$. davidiana geno-

Table 4. Juice characteristics of the fruit of Prunus persica, P. davidiana, and hybrid genotypes.

\begin{tabular}{lccc}
\hline \hline & & $\begin{array}{c}\text { Titratable } \\
\text { acidity } \\
\left(\mathrm{meq} \cdot \mathrm{L}^{-1}\right)\end{array}$ & $\begin{array}{c}\text { SSC } \\
\left({ }^{\circ} \text { Brix }\right)\end{array}$ \\
Genotype & $\mathrm{pH}$ & $157.9 \mathrm{a}$ & $12.0 \mathrm{~b}$ \\
Summergrand & $3.64 \mathrm{e}^{\mathrm{z}}$ & $91.6 \mathrm{~b}$ & $11.0 \mathrm{~b}$ \\
Bailey & $4.12 \mathrm{c}$ & $70.4 \mathrm{~b}$ & $14.7 \mathrm{a}$ \\
Pamirskij & $4.35 \mathrm{~b}$ & $171.4 \mathrm{a}$ & $15.4 \mathrm{a}$ \\
SxD 31 & $3.81 \mathrm{~d}$ & $180.6 \mathrm{a}$ & $12.3 \mathrm{~b}$ \\
SxD 17 & $3.80 \mathrm{~d}$ & $185.2 \mathrm{a}$ & $8.3 \mathrm{c}$ \\
P. davidiana 2 & $4.38 \mathrm{~b}$ & $163.6 \mathrm{a}$ & $7.4 \mathrm{c}$ \\
P. davidiana P 1908 & $4.60 \mathrm{a}$ &
\end{tabular}

$\overline{{ }^{\mathrm{z}} \text { Mean of } 10 \text { fruit. Mean separation within columns according to Tukey's }}$ test, $P<0.05$. 
Table 5. Carbohydrate concentration ( $\mathrm{mg}^{-\mathrm{g}^{-1}}$ dry weight) of the fruit flesh of Prunus persica, P. davidiana, and hybrid genotypes.

\begin{tabular}{|c|c|c|c|c|c|c|}
\hline Genotype & Sorbitol & Glucose & Fructose & Sucrose & $\begin{array}{c}\text { Total } \\
\text { soluble } \\
\text { carbohydrates }\end{array}$ & Starch \\
\hline Summergrand & $20.8{b c^{z}}^{2}$ & $81.0 \mathrm{~b}$ & $125.5 \mathrm{~b}$ & $635.0 \mathrm{a}$ & $868.4 \mathrm{ab}$ & $1.2 \mathrm{bcd}$ \\
\hline Bailey & $40.1 \mathrm{ab}$ & $67.8 \mathrm{bc}$ & $5.1 \mathrm{f}$ & $360.1 \mathrm{~b}$ & $479.5 \mathrm{c}$ & $2.3 \mathrm{a}$ \\
\hline Pamirskij & $60.5 \mathrm{a}$ & $41.7 \mathrm{~cd}$ & $69.0 \mathrm{~d}$ & $744.5 \mathrm{a}$ & $921.0 \mathrm{a}$ & $0.7 \mathrm{cde}$ \\
\hline SxD 31 & $13.3 \mathrm{bc}$ & $207.1 \mathrm{a}$ & $99.8 \mathrm{c}$ & $414.3 \mathrm{~b}$ & $739.9 \mathrm{~b}$ & $1.6 \mathrm{abc}$ \\
\hline SxD 17 & $17.5 \mathrm{bc}$ & $180.7 \mathrm{a}$ & $174.2 \mathrm{a}$ & $484.6 \mathrm{~b}$ & $862.5 \mathrm{ab}$ & $1.7 \mathrm{ab}$ \\
\hline P. davidiana 2 & $3.9 \mathrm{c}$ & $10.0 \mathrm{e}$ & 17.8 ef & $38.2 \mathrm{c}$ & $78.3 \mathrm{~d}$ & $0.3 \mathrm{e}$ \\
\hline P. davidiana P 1908 & $2.5 \mathrm{c}$ & $21.8 \mathrm{de}$ & $30.7 \mathrm{e}$ & $79.8 \mathrm{c}$ & $140.1 \mathrm{~d}$ & $0.6 \mathrm{de}$ \\
\hline
\end{tabular}

${ }^{\mathrm{z}}$ Mean of five fruit. Mean separation within columns according to Tukey's test, $P<0.05$.

types probably contributed to low-quality of fruit flesh, through their impact on bitterness and astringency. Robertson et al. (1988) emphasized that low quality genotypes, including 'Bailey', differed greatly from high quality genotypes in phenolic content. Karakurt et al. (2000) showed that accumulation of soluble phenolics and chlorogenic acid appeared to be associated with the development of off-flavor in nonmelting flesh peaches. Our data indicated a total caffeoylquinic acid concentration twice as high in $P$. davidiana fruit than in 'Bailey' fruit. $P$. davidiana fruit also had a high content of chlorogenic acid isomers, cryptochlorogenic acid and mainly neochlorogenic acid. Caffeoylquinic acids could be involved in flesh bitterness, although this role is controversial (Macheix et al., 1990). The relative bitterness of the different caffeoylquinic acid isomers is unknown and needs to be further investigated. However, the predominant accumulation of neochlorogenic and cryptochloro-genic acid could be important for fruit quality. It was previously reported that apricot genotypes with a high content of neochlorogenic acid (Radi et al., 1997) or apple genotypes with a high content of cryptochlorogenic acid (Amiot et al., 1992) tended to show less browning. These caffeoylquinic isomers are poorer substrates for polyphenol oxidases than chlorogenic acid and the ratio between the different compounds could play a major role in the control of browning. Indeed, Cheng and Crisosto (1995) showed a good correlation between browning and chlorogenic acid concentration in peach genotypes. Caffeoylquinic acids could also play a role in the fruit resistance to brown rot [Monilinia fruticola (G. Wint.)] since resistance is associated with high levels of caffeic and chlorogenic acids (Gradziel et al., 1998). Catechin was abundant for both $P$. davidiana genotypes, although significantly higher in $P$. davidiana 2 . Proanthocyanidin concentrations were also very high in $P$. davidiana 2 , but they were similar in $P$. davidiana P 1908 and P. persica fruit. Catechin and proanthocyanidins are involved in astringency and bitterness perception (Macheix et al., 1990). The ratio between monomers, oligomers and polymers has a strong influence on these taste parameters since relative astringency increases and bitterness decreases with molecular weight (Macheix et al., 1990). In our study, the high level of proanthocyanidins in $P$. davidiana 2 fruit was clearly associated with a highmean astringency score, whereas fruit from $P$. davidiana P 1908 showed both lower proanthocyanidin concentration and mean astringency score. Anthocyanins were not detected in the skin of both $P$. davidiana fruit and in green-fruited $P$. persica, 'Pamirskij'.

Volatile compounds should be included in further studies because of their contribution to odor and flavor (Visai and Vanolli, 1997). However, Robertson et al. (1988) failed to identify the volatiles responsible for the floral aromas of low-quality peach genotypes including 'Bailey'.
COMPARISON BETWEEN LOW-QUALITY GENOTYPES AND $P$. persica $X \boldsymbol{P}$. davidiana HYBRIDS, AND CONSEQUENCES ON BREEDING. Most compounds analyzed from $P$. persica $\times P$. davidiana hybrids were very similar to low-quality peach genotypes such as 'Bailey'. However, some compounds were closer to high-quality genotypes than low-quality genotypes.

Total soluble sugar concentration in $P$. persica $\times$ P. davidiana fruit did not differ from that in 'Summergrand' fruit. Despite the very low sugar concentration in $P$. davidana, $P$. davidianaderived material with an acceptable sugar concentration should thus be easily obtained by recurrent backcrossing. However, genotypes with a low sugar content might appear if $P$. davidianaderived hybrids are intercrossed. Another concern about sugar composition may be that glucose, with a lower relative sweetness (Pangborn, 1963), is far more abundant in $P$. persica $\times P$. davidiana fruit than in any of their parents. The genetic basis of

Table 6. Organic acid concentration ( $\mathrm{mg} \cdot \mathrm{g}^{-1} \mathrm{dry}$ weight) of the fruit flesh of Prunus persica, P. davidiana, and hybrid genotypes.

\begin{tabular}{lcccc}
\hline & & & & \\
Genotype & Malic & Citric & Quinic & $\begin{array}{c}\text { Total } \\
\text { organic } \\
\text { acids }\end{array}$ \\
\hline Summergrand & $33.1 \mathrm{c}^{\mathrm{z}}$ & $28.6 \mathrm{a}$ & $17.4 \mathrm{a}$ & $80.1 \mathrm{bc}$ \\
Bailey & $29.2 \mathrm{c}$ & $16.7 \mathrm{bc}$ & $17.8 \mathrm{a}$ & $64.6 \mathrm{~cd}$ \\
Pamirskij & $19.3 \mathrm{c}$ & $12.6 \mathrm{~cd}$ & $15.4 \mathrm{a}$ & $48.2 \mathrm{~d}$ \\
SxD 31 & $49.7 \mathrm{~b}$ & $21.5 \mathrm{ab}$ & $18.2 \mathrm{a}$ & $90.6 \mathrm{~b}$ \\
SxD 17 & $48.5 \mathrm{~b}$ & $23.8 \mathrm{ab}$ & $14.8 \mathrm{ab}$ & $88.1 \mathrm{~b}$ \\
P. davidiana 2 & $114.1 \mathrm{a}$ & $4.4 \mathrm{de}$ & $7.9 \mathrm{c}$ & $127.2 \mathrm{a}$ \\
$P$. davidiana P 1908 & $121.0 \mathrm{a}$ & $2.5 \mathrm{e}$ & $11.0 \mathrm{bc}$ & $135.4 \mathrm{a}$
\end{tabular}

${ }^{\mathrm{z}}$ Mean of five fruit. Mean separation within columns according to Tukey's test, $P<0.05$.

Table 7. Amino acid concentration ( $\mathrm{mg} \cdot \mathrm{g}^{-1}$ dry weight) of the fruit flesh of Prunus persica, $P$. davidiana, and hybrid genotypes.

\begin{tabular}{lcccc}
\hline \hline Genotype & Asparagine & Aspartate & Serine & $\begin{array}{c}\text { Total } \\
\text { amino } \\
\text { acids }\end{array}$ \\
\hline Summergrand & $24.75 \mathrm{bc}^{2}$ & $0.86 \mathrm{~b}$ & $0.46 \mathrm{~b}$ & $27.89 \mathrm{bc}$ \\
Bailey & $37.83 \mathrm{~b}$ & $0.77 \mathrm{~b}$ & $1.19 \mathrm{a}$ & $42.79 \mathrm{~b}$ \\
Pamirskij & $23.59 \mathrm{bc}$ & $0.81 \mathrm{~b}$ & $0.86 \mathrm{ab}$ & $27.60 \mathrm{bc}$ \\
SxD 31 & $16.01 \mathrm{c}$ & $1.08 \mathrm{~b}$ & $0.46 \mathrm{~b}$ & $19.71 \mathrm{c}$ \\
SxD 17 & $21.41 \mathrm{c}$ & $0.96 \mathrm{~b}$ & $0.70 \mathrm{~b}$ & $25.53 \mathrm{c}$ \\
$P$. davidiana 2 & $67.69 \mathrm{a}$ & $1.02 \mathrm{~b}$ & $0.58 \mathrm{~b}$ & $71.51 \mathrm{a}$ \\
$P$. davidiana $\mathrm{P} 1908$ & $75.82 \mathrm{a}$ & $1.80 \mathrm{a}$ & $1.26 \mathrm{a}$ & $82.42 \mathrm{a}$
\end{tabular}

${ }^{\mathrm{z}}$ Mean of five fruit. Mean separation within columns according to Tukey's test, $P<0.05$. 
Table 8. Hydroxycinnamic acid, catechin and proanthocyanidin (PA) concentration $\left(\mathrm{mg}^{\mathrm{g}} \mathrm{g}^{-1} \mathrm{dry}\right.$ weight) of the fruit flesh of Prunus persica, $P$. davidiana, and hybrid genotypes.

\begin{tabular}{|c|c|c|c|c|c|c|}
\hline Genotype & $3^{\prime} \mathrm{CQ}^{\mathrm{z}}$ & $4^{\prime} \mathrm{CQ}^{\mathrm{z}}$ & $5^{\prime} \mathrm{CQ}^{\mathrm{z}}$ & Sum $\mathrm{CQ}^{\mathrm{y}}$ & Catechin & $\mathrm{PA}^{\mathrm{x}}$ \\
\hline Summergrand & $1.17 \mathrm{~d}^{\mathrm{w}}$ & $0.02 \mathrm{~b}$ & $0.84 \mathrm{bc}$ & $2.03 \mathrm{~cd}$ & $0.19 \mathrm{~d}$ & $0.37 \mathrm{~b}$ \\
\hline Bailey & $1.66 \mathrm{~cd}$ & $0.04 \mathrm{~b}$ & $3.07 \mathrm{a}$ & $4.78 \mathrm{~b}$ & $0.83 \mathrm{bc}$ & $1.21 \mathrm{~b}$ \\
\hline Pamirskij & $0.53 \mathrm{~d}$ & $0.01 \mathrm{~b}$ & $1.27 \mathrm{~b}$ & $1.80 \mathrm{~d}$ & $0.35 \mathrm{~cd}$ & $0.39 \mathrm{~b}$ \\
\hline SxD 31 & $4.10 \mathrm{~b}$ & $0.10 \mathrm{~b}$ & $1.10 \mathrm{~b}$ & $5.31 \mathrm{~b}$ & $0.33 \mathrm{~cd}$ & $1.47 \mathrm{~b}$ \\
\hline SxD 17 & $3.24 \mathrm{bc}$ & $0.07 \mathrm{~b}$ & $0.90 \mathrm{~b}$ & $4.21 \mathrm{bc}$ & $0.49 \mathrm{~cd}$ & $1.78 \mathrm{~b}$ \\
\hline P. davidiana 2 & $9.00 \mathrm{a}$ & $0.36 \mathrm{a}$ & $0.15 \mathrm{c}$ & $9.52 \mathrm{a}$ & $5.13 \mathrm{a}$ & $6.51 \mathrm{a}$ \\
\hline P. davidiana P 1908 & $8.32 \mathrm{a}$ & $0.37 \mathrm{a}$ & $0.15 \mathrm{c}$ & $8.85 \mathrm{a}$ & $1.46 \mathrm{~b}$ & $0.81 \mathrm{~b}$ \\
\hline
\end{tabular}

${ }^{\mathrm{z}}$ Mean of five fruit. 3'CQ, neochlorogenic acid; 4'CQ, cryptochlorogenic acid; 5'CQ, chlorogenic acid.

'Sum CQ, sum of 3'CQ, 4'CQ and 5'CQ.

xPA, proanthocyanidins, were estimated based on their conversion to anthocyanidins upon acid hydrolysis.

wMean separation within columns according to Tukey's test, $P<0.05$.

these transgressive values would be worth investigating. Organic acid concentration in $P$. persica $\times P$. davidiana hybrids was significantly higher than in 'Bailey' and 'Pamirskij' fruit, but did not differ from that of high-quality 'Summergrand'. As with sugar, no major problem should be encountered in producing hybrids with satisfactory organic acid concentrations.

Lower phenolic concentration should be the main target of fruit quality breeding in $P$. davidiana-derived material. The total concentration of CQ in P. persica $\times$ P. davidiana hybrids was similar to that observed in 'Bailey' which, according to the findings of Robertson et al. (1988), was excessive. Proanthocyanidin concentration did not differ significantly between highquality $P$. persica genotypes, 'Bailey' and $P$. persica $\times P$. davidiana hybrids. However, proanthocyanidin concentrations in 'Bailey' and $P$. persica $\times P$. davidiana hybrid fruit were 4 to 6 times higher than in 'Summergrand' and 'Pamirskij' fruit, and significant differences in the perception of astringency were noticed between these two groups. This may indicate that proanthocyanidin concentration could also be excessive in 'Bailey' and $P$. persica $\times P$. davidiana hybrids. The genetic gain necessary to recover material with acceptable phenolic and proanthocyanidin concentration would be comparable when using low-quality $P$. persica genotypes or $P$. persica $\times$ P. davidiana hybrids as starting material. Hansche and Boynton (1986) found moderately high narrowsense heritabilities for polyphenol content $\left(h^{2}=0.4\right)$, whereas Bailey and French (1949) considered high polyphenol content as genetically dominant. Proanthocyanidin concentration of $P$. persica $\times P$. davidiana hybrids was higher than that of both parents. The reasons for such transgressive values would be worth studying.

Skin anthocyanin contents in $P$. persica $\times P$. davidiana hybrids were of the same order of magnitude as in 'Bailey'. They appear to be closer to those observed in P. davidiana than to those of 'Summergrand' on a linear scale. Percentage of skin red blush was shown to be a highly heritable trait in peach $\left(\mathrm{h}^{2}=0.68\right)$, allowing a rapid genetic advance (Souza et al., 2000), although lower heritability values were reported by Hansche and Boynton (1986). Red blush should therefore be easily improved.

The high variability observed between $P$.persica and $P$. davidiana genotypes for the different compounds studied opens the way for a quantitative genetic study using offspring derived P. persica $\times P$. davidiana crosses. The detection of quantitative trait loci (Prioul et al., 1997) controlling the fruit concentration of soluble sugars, organic acids and phenolic compounds would be a first step towards the development of marker assisted selection for these characters.

Metabolic ORIgin of the biochemical Differences. Hy- potheses on the enzyme(s) responsible for changes in concentration can be formulated when the synthesis and degradation pathways of a primary or secondary metabolite are described in the literature for plants, and especially for fruit. For instance, the variations in the sucrose to hexose ratio, from $\approx 1$ in SxD31 to 7 in 'Pamirskij', may result from differences in expression and activity of acid invertase, as shown for differences between cultivated and wild tomato (Klann et al., 1993). The metabolic origin of the high malic acid content in $P$. davidiana genotypes may result from a high synthesis by phosphoenolpyruvate carboxylase during early stages of development (Moing et al. 2000), a low degradation during maturation (Taureilles-Saurel et al., 1995; Ruffner et al., 1984) and/ or a high storage capacity in the vacuole.

Although the metabolism of phenolic compounds is quite complex, the differences observed in the accumulation of anthocyanins and other phenolic compounds in fruit tissues may result either from differences in the activity of key enzymes in the phenylpropanoid or flavonoid pathways, i.e., phenylalanineammonia-lyase or chalcone synthase, or from specific enzyme activities involved in the synthesis of particular compounds. In $P$. davidiana genotypes, the high level of catechin and proanthocyanidins may result from a high activity of dihydroflavonol reductase which is involved in the control of condensed tannins biosynthesis (Carron et al., 1994).

The above hypotheses need to be tested by measuring the metabolite concentrations and total enzyme activities during the fruit development of the genotypes studied in the present work.

Table 9. Cyanidin-3-glucoside concentration ( $\mu \mathrm{g} \cdot \mathrm{g}^{-1}$ dry weight) of the fruit flesh and epidermis of Prunus persica, $P$. davidiana, and hybrid genotypes.

\begin{tabular}{lcc}
\hline & \multicolumn{2}{c}{ Cyanidin-3-glucoside } \\
\cline { 2 - 3 } Genotype & Flesh & Skin \\
\hline Summergrand & $255 \mathrm{ab}^{\mathrm{z}}$ & $6486 \mathrm{a}$ \\
Bailey & $310 \mathrm{a}$ & $66 \mathrm{~b}$ \\
Pamirskij & $\mathrm{ND}^{\mathrm{y}} \mathrm{c}$ & ND b \\
SxD 31 & $166 \mathrm{~b}$ & $350 \mathrm{~b}$ \\
SxD 17 & $315 \mathrm{a}$ & $154 \mathrm{~b}$ \\
$P$. davidiana 2 & ND c & ND b \\
$P$. davidiana P 1908 & ND c & ND b
\end{tabular}

${ }^{\mathrm{z}}$ Mean of five fruit. Mean separation within columns according to Tukey's test, $P<0.05$.

${ }^{\mathrm{y}} \mathrm{ND}=$ not detected. 


\section{Conclusion}

When compared to $P$. persica fruit, $P$. davidiana fruit are characterized by low concentrations of soluble sugars and citric acid, and high concentrations of malic acid, neochlorogenic acid and proanthocyanidins. Comparisons among P. persica, $P$. davidiana and, P.persica $\times$ P. davidiana hybrids support the view that genotypes with acceptable fruit quality should be obtained from $P$. davidiana, with a simple breeding strategy. However, better knowledge of the metabolic and genetic control of fruit size, and sugar, organic acid and phenolic accumulation appears crucial in order to make progress in the use of poor-quality fruit germplasm from $P$. davidiana for the development of pathogenresistant peach cultivars. Possible relationships between fruit composition and plant resistance should also be investigated.

\section{Literature cited}

Amiot, M.J., M. Tacchini, S. Aubert, and J. Nicolas. 1992. Phenolic composition and browning susceptibility of various apple cultivars at maturity. J. Food Sci. 57:958-962.

Bailey, J.S. and A.P. French. 1949. The inheritance of certain fruit and foliage characters in the peach. Mass. Agr. Expt. Sta. Bul. 452.

Bassi, D. and R. Selli. 1990. Evaluation of fruit quality in peach and apricot. Adv. Hort. Sci. 4:107-112.

Brady, C.J. 1993. Stone fruit, p. 379-404. In: G.B. Seymour, J.E. Taylor, and G.A. Tucker (eds.). Biochemistry of fruit ripening. Chapman \& Hall, London, U.K.

Byrne, D.H., A.N. Nikolic, and E.E. Burns. 1991. Variability in sugars, acids, firmness, and color characteristics of 12 peach genotypes. J. Amer. Soc. Hort. Sci. 116:1004-1006.

Carron, T.R., M.P. Robbins, and P. Morris. 1994. Genetic modification of condensed tannin biosynthesis in Lotus corniculatus. I. Heterologous antisense dihydroflavonol reductase down-regulates tannin accumulation in "hairy root" cultures. Theor. Appl. Genet. 87:1006-1015.

Cheng, G.W. and C.H. Crisosto. 1995. Browning potential, phenolic composition, and polyphenoloxydase activity of buffer extracts of peach and nectarine skin tissue. J. Amer. Soc. Hort. Sci. 120:835-838.

Cohen, S.A. and P. Michaud. 1993. Synthesis of a fluorescent derivatizing reagent, 6-aminoquinolyl-N-hydroxysuccinimidyl carbamate, and its application for the analysis of hydrolysate amino acids via high-performance liquid chromatography. Anal. Biochem. 211:279-287.

Fideghelli, C., G. Della Strada, F. Grassi, and G. Morico. 1998. The peach industry in the world: Present situation and trend. Acta Hort. 465:29-40.

Gradziel, T.M., M.A. Thorpe, R.M. Bostock, and S. Wilcox. 1998. Breeding for brown rot (Monilinia fructicola) resistance in clingstone peach with emphasis on the role of fruit phenolics. Acta Hort. 465:161-170.

Hansche, P.E. and B. Boynton. 1986. Heritability of enzymatic browning in peaches. HortScience 21:1195-1197.

Herrmann, K. 1989. Occurence and contents of hydroxycinnamic and hydroxybenzoic acid compounds in food. Critical Rev. Food Sci. Nutr. 28:315-347.

Hollander, M. and D.A. Wolfe. 1973. Nonparametric statistical methods. John Wiley, New York.

Karakurt, Y.,D.J.Huber, and W.B. Sherman. 2000.Development of off-flavour in non-melting flesh peach genotypes. J. Sci. Food Agr. 80:1841-1847.

Kervella, J., T. Pascal, F. Pfeiffer, and E. Dirlewanger. 1998. Breeding for multiresistance in peach tree. Acta Hort. 465:177-184.

Klann, E.M., R.T. Chetelat, and A.B. Bennett. 1993. Expression of acid invertase gene controls sugar composition in tomato (Lycopersicon) fruit. Plant Physiol. 103:863-870.

Layne, R.E.C., and P.Y. Jui, 1994. Genetically diverse peach seedling rootstocks affect long-term performance of 'Redhaven' peach on Fox sand. J. Amer. Soc. Hort. Sci. 119:1303-1311.

Li, Z. 1984. Peach germplasm and breeding in China. HortScience 19:348351.

Macheix, J.J., A. Fleuriet, and J. Billot. 1990. Fruit phenolics. CRC Press,
Boca Raton, Fla.

Massonié, G., P. Maison, R. Monet, and C. Grasselly. 1982. Résistance au puceron vert du pêcher Myzus persicae Sulzer (Homoptera Aphididae) chezPrunus persica (L.) Batschet d'autres espèces de Prunus. Agronomie 2:63-70.

Moing, A., F. Carbonne, M.H. Rashad, and J.P. Gaudillère. 1992. Carbon fluxes in mature peach leaves. Plant Physiol. 100:1878-1884.

Moing, A., F. Carbonne, B. Zipperlin, L. Svanella, and J.P. Gaudillère. 1997. Phloem loading in peach: Symplastic or apoplastic? Physiol. Plant. 101:498-496.

Moing, A., L. Svanella, D. Rolin, M. Gaudillère, J.P. Gaudillère, and R. Monet. 1998. Compositional changes during the fruit development of two peach cultivars differing in juice acidity. J. Amer. Soc. Hort. Sci. 123:770-775.

Moing, A., C. Rothan, L. Svanella, D. Just, P. Diakou, J.P. Gaudillère, and R. Monet. 2000. Role of phosphoenolpyruvate carboxylase in organic acid accumulation during peach fruit development. Physiol. Plant. 108:110.

Möller, B., and K. Herrmann. 1982. Analysis of quinic acid esters of hydroxycinnamic acids in plant material by capillary gas chromatography and high-performance liquid chromatography. J. Chromatogr. 241:371-379.

Okie, W.R. 1998. Peach and nectarine varieties. USDA-ARS Agr. Hdbk. 714.

Pangborn, R.M. 1963. Relative taste intensities of selected sugars and organic acids. J. Food Sci. 28:726-733.

Porter, L.J, L.N. Hrstich, and B.G. Chan. 1986. The conversion of procyanidins and prodelphinidins to cyanidin and delphinidin. Phytochemistry 25:223-230.

Prioul, J.L., S. Quarries, M. Causse, and D. de Vienne. 1997. Dissecting complex physiological functions through the use of molecular quantitative genetics. J. Expt. Bot. 311:1151-1163.

Radi, M., M. Mahrouz, A. Jaouad, M. Tacchini, S. Aubert, M. Hugues, and M.J. Amiot. 1997. Phenolic composition, browning susceptibility, and carotenoid content of several apricot cultivars at maturity. HortScience 32:1087-1091.

Robertson, J.A., F.I. Meredith, and R. Scorza. 1988. Characteristics of fruit from high- and low-quality peach cultivars. HortScience 23:1032-1034. Ruffner, H.P., D. Possner, S. Brem, and D.M. Rast. 1984. The physiological role of malic enzyme in grape ripening. Planta 160:444-448.

Scorza, R., L.G. May, B. Purnell, and B. Upchurch. 1991. Differences in number and area of mesocarp cells between small- and large-fruited peach cultivars. J. Amer. Soc. Hort. Sci. 116:861-864.

Scorza, R., S.A. Mehlenbacher, and G.W. Lightner. 1985. Inbreeding and coancestry of freestone peach cultivars of the eastern United States and implications for peach germplasm improvement. J. Amer. Soc. Hort. Sci. 110:547-552.

Scorza, R. and W.R. Okie. 1990. Peaches, p. 175-231. In: J.N. Moore and J.R. Ballington, Jr. (eds). Genetic ressources of temperate fruit and nut crops. Acta Hort., Intl. Soc. Hort. Sci., Wageningen, Holland.

Senter, S.D. and A. Callahan. 1990. Variability in the quantities of condensed tannins and other major phenols in peach fruit during maturation. J. Food Sci. 55:1585-1587.

Shoferistov, E.P. 1988. Nectarine breeding in Crimea. Acta Hort. 224:281284.

Souza V.A.B., D.H. Byrne, and J.F. Taylor. 2000. Heritability, genetic and phenotypic correlations, and predicted selection response of quantitative traits in peach. II. An analysis of several fruit traits. J. Amer. Soc. Hort. Sci. 123:604-611.

Taureilles-Saurel, C., C.G. Romieu, J.P. Robin, and C. Flanzy. 1995. Grape (Vitis vinifera $\mathrm{L}$.) malate dehydrogenase. II. Characterisation of the major mitochondrial and cytosolic isoforms and their role in ripening. Amer. J. Enol. Viticult. 46:29-36.

Van Blaricom, L.O. and T.N. Senn. 1967. Anthocyanin pigments in freestone peaches grown in the southeast. Proc. Amer. Soc. Hort. Sci. 90:541-545.

Visai, C. and M. Vanolli. 1997. Volatile compound production during growth and ripening of peaches and nectarines. Scientia Hort. 70:15-24. 